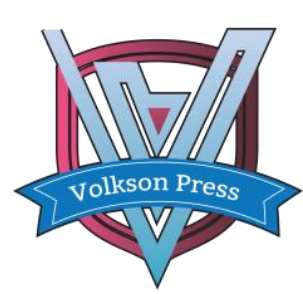

Contents List available at VOLKSON PRESS

Economics \& Management Innovations(EMI)

DOI : http://doi.org/10.26480/icemi.01.2017.90.93

\title{
Research on the Chinese Fossil Energy and New Energy Subsidy Policy from the Perspective of Game Theory
}

\author{
Ju Keyi ${ }^{1}$, Li Changle ${ }^{2, *}$
}

1,2 School of Economics and Management, Jiangsu University of Science and Technology, Zhenjiang, Jiangsu 212000, China

*Email:1728178105@qq.com

This is an open access article distributed under the Creative Commons Attribution License, which permits unrestricted use, distribution, and reproduction in any medium, provided the original work is properly cited.

\section{ARTICLE DETAILS}

\section{Article History:}

Received 02 october 2017

Accepted 06 october 2017

Available online 11 october 2017

Keywords:

Energy subsidies, Fossil energy,

New energy, Cournot game

\section{ABSTRACT}

At present, despite the government have higher subsidies for the energies, the efficient energy subsidies are not adequate. In this paper, Cournot game was built based on the government subsidies for fossil energy and new energy power generation enterprises, about electricity production from fossil energy and new energy enterprises and market prices using the game analysis. The subsidies according to relationship of size among national level of carbon emissions $M_{0}$ and fossil energy carbon emission levels $M_{1}$ and new energy carbon emission levels $M_{2}$, can be classified three situation: $\mathrm{M}_{0}>\mathrm{M}_{1}>\mathrm{M}_{2}, \mathrm{M}_{1}>\mathrm{M}_{0}>\mathrm{M}_{2}, \mathrm{M}_{1}>\mathrm{M}_{2}>\mathrm{M}_{0}$. Then compare three situations, so that provide basis and reference for the government subsidies.

\section{Introduction}

Planning for its 13th Five Year Plan put forward seven major strategic task: increasing energy production at home, pressing ahead with energy conservation, optimizing energy structure, vigorously develop hydro, nuclear, wind, solar and geothermal, encouraging international energy cooperation, promoting the innovation of energy technological and system, improving energy supervision. The target is find a right balance between energy security, efficiency and cleaner, achieve the sustainable energy development.

(Lin et al, 2016) ${ }^{1}$ studies prove that China has been reducing energy subsidies since 2013 and subsidies have been fully cancelled at financial sense to 2015. Nevertheless, not only cross-subsidy still very serious but also mountains of coal consumption caused high externality environmental cost, makes energy subsidies in the aspect of externality environmental cost still exist. Thus it can be seen that we are still a long way to go in the process of elimination energy subsidies.

At present, there already had some references have discussed the game question between government, fossil energy and new energy in the subsidies. (Zhu and Dou 2011) ${ }^{2}$ established a three-stage game model of that considered product green level and government subsidies analysis in the green supply chain management, and through numerical simulation discussed the effects of various parameters. (Liu 2013) ${ }^{3}$ under the condition of reasonable supposition, the government and enterprises income opportunity function of developed new energy industries determines their developing wishes. When Nash Equilibrium strategies are both government and business develop new energy industries, can make social welfare maximizing. (Zhang et al 2014) ${ }^{4}$ explored government and business strategies choice and dependence change in the course of energy conservation and emissions reduction application and issue through signal game. Then using MATLAB made numerical simulation to verify the effectiveness of the model. (Zhang 2014) ${ }^{5}$ after by analysis of collusion between government and firms, they think that establish a more comprehensive, much dimensional examination index and give full play inquiries and supervision of the public and medium can effective restrict collusive behaviors. (He and Wang 2014) ${ }^{6}$ focused the subjects of the game on the government and the low carbon supply chain core enterprise, and analyzed the costs and gains of both government and core enterprise under the different game strategies. Then constructed the dynamically evolutionary game model, and acquire the evolutionarily stable strategy of monitor game between the government and enterprise. (Hammond D , Beullens P 2007)7 established the Cournot game model based on whole information, analyzed function in reverse supply chain management about wasted electrical and electronic equipment directive(WEEE directive) of the government especially the European Union.(Rui Zhao and Gareth Neighbour 2012) ${ }^{8}$ put forward a strategy choices of manufacturers use game theory analysis under the background of green supply chain management, to reduce the life cycle of materials and carbon emissions of environmental risk.

Overall, on content, existing researches are mainly focused on the questions of subsidies rationality or not and role of how, subsidies times, subsidies types. On the microscopic level, multitudinous researches for these questions like government subsidies and concrete behaviors in specific areas. In this paper, for different carbon emission standards were used to classify reviewed studies. Aimed at elaborate analysis the fossil fuels and new energy subsidies of changes when unit of carbon emissions subsidies line change.

\section{Model Building}

\subsection{Model Assumes}

This research mainly contains two enterprises: fossil energy (producer 1 ) and new energy (producer 2) enterprises. In the process of electricity generation, fossil energy produced by the unit of carbon emissions is higher than new energy. But because of fossil energy generation enjoys mature technology, new energy generation technology is not mature, so fossil energy costs less than new energy power generation costs. Set unit cost respectively $\mathrm{C}_{1}$ and $\mathrm{C}_{2}$, so $\mathrm{C}_{2}>\mathrm{C}_{1}$. Through the above understanding, this paper based on the assumptions:

(1) The power on the market is mainly provided by fossil energy and new energy.

(2) Two-type enterprises are simply obeys relevant policy-systems by government.

(3) Electricity price adopt sales price, and there is no difference in the electricity price.

(4) Government revenue is the synthesis of enterprises benefits, government subsidies and taxes.

(5) Direct subsidies to new energy $t_{2}$ is greater than the direct subsidies for fossil fuels $t_{1}$, so $t_{2}>t_{1}$.

(6) Fossil energy unit carbon emissions $M_{1}$ is greater than the new energy unit carbon emissions $\mathrm{M}_{2}$, so $\mathrm{M}_{1}>\mathrm{M}_{2}$ 
2.2 Model Building

Cournot game was applied in this study, fossil energy generating capacity for $\mathrm{q}_{1}$ and new energy generating capacity for $\mathrm{q}_{2}$. Set market inverse demand function for

$\mathrm{p}=\mathrm{P}(\mathrm{Q})=\mathrm{a}-\mathrm{bQ}=\mathrm{a}-\mathrm{b}\left(\mathrm{q}_{1}+\mathrm{q}_{2}\right),[\mathrm{a}>0, \mathrm{~b}>0]$

In this paper, state subsidies on fossil energy and new energy consist of two parts: direct subsidies to the enterprises, additional subsidies to the enterprises according to the unit carbon emissions. Subsidies size and unit carbon emissions exists linear correlation. National unit of carbon emission levels for $\mathrm{M}_{0}$, when enterprise unit carbon emissions than $\mathrm{M} 0$, need to tax; when enterprise unit carbon emissions than M0, need to subsidies.

\section{Solve Model under Different Situation}

\subsection{Situation 1: $\mathrm{M}_{2}<\mathrm{M}_{1}<\mathrm{M}_{0}$}

The first situation: government subsidies for enterprise of unit carbon emissions less than $M_{0}^{A}$ (to distinguish the different situation of $M_{0}$, here with $\mathrm{M}_{0}^{\mathrm{A}}$; unit of the coefficient of subsidies for $\mathrm{t}_{0}$ ), at this moment, $\mathrm{M}_{1}<$ $\mathrm{M}_{0}^{\mathrm{A}}, \mathrm{M}_{2}<\mathrm{M}_{0}^{\mathrm{A}}$, revenue function is:

$\pi_{1}=\mathrm{q}_{1}\left[\mathrm{P}\left(\mathrm{q}_{1}+\mathrm{q}_{2}\right)-\mathrm{C}_{1}+\mathrm{t}_{1}+\mathrm{t}_{0}\left(\mathrm{M}_{0}^{\mathrm{A}}-\mathrm{M}_{1}\right)\right]$

$\pi_{2}=\mathrm{q}_{2}\left[\mathrm{P}\left(\mathrm{q}_{1}+\mathrm{q}_{2}\right)-\mathrm{C}_{2}+\mathrm{t}_{2}+\mathrm{t}_{0}\left(\mathrm{M}_{0}^{\mathrm{A}}-\mathrm{M}_{2}\right)\right]$.

\subsubsection{The optimal equilibrium output}

Both producers choose their optimal equilibrium output, for the first order derivatives equal to zero, namely:

$$
\left\{\begin{array}{l}
\frac{\partial \pi_{1}}{\partial q_{1}}=a-b q_{2}-C_{1}-2 b q_{1}+t_{1}+t_{0}\left(M_{0}^{A}-M_{1}\right)=0 \\
\frac{\partial \pi_{2}}{\partial q_{2}}=a-b q_{1}-C_{2}-2 b q_{2}+t_{2}+t_{0}\left(M_{0}^{A}-M_{2}\right)=0
\end{array}\right.
$$

To :

$$
\left\{\begin{array}{l}
\mathrm{q}_{1}^{\mathrm{Cl}}=\frac{\mathrm{a}-2 \mathrm{C}_{1}+\mathrm{C}_{2}+2 \mathrm{t}_{1}-\mathrm{t}_{2}+\mathrm{t}_{0}\left(\mathrm{M}_{0}^{\mathrm{A}}-2 \mathrm{M}_{1}+\mathrm{M}_{2}\right)}{3 \mathrm{~b}} \\
\mathrm{q}_{2}^{\mathrm{Cl}}=\frac{\mathrm{a}-2 \mathrm{C}_{2}+\mathrm{C}_{1}+2 \mathrm{t}_{2}-\mathrm{t}_{1}+\mathrm{t}_{0}\left(\mathrm{M}_{0}^{\mathrm{A}}+\mathrm{M}_{1}-2 \mathrm{M}_{2}\right)}{3 \mathrm{~b}}
\end{array}\right.
$$

3.1.2 The effects of variables on the equilibrium

The first derivative of $t_{1}, t_{2}, t_{0}, M_{1}, M_{2}, M_{0}^{A}$ for $q_{1}^{c 1}$ and $q_{2}^{c 1}$, we can draw:

(1) Direct subsidies is proportional to the output; fossil energy enterprise have the higher unit carbon emissions $\mathrm{M}_{1}$, the smaller market share; for $t_{0}$, when $2 M_{1}>M_{0}+M_{2}$, the first order derivatives is less than 0 . So, with the increase of $t_{0}$, fossil energy generating capacity will be reduced, this means that it will promote the development of new energy; when $2 \mathrm{M}_{1}<\mathrm{M}_{0}+\mathrm{M}_{2}$, the first order derivatives is more than 0 . So, with the increase of $t_{0}$, fossil energy generating capacity will increase, this means that it will restrain the development of new energy.

(2) New energy enterprise has the higher unit carbon emissions $M_{2}$, the smaller market share; for $t_{0}$, when $2 M_{2}>M_{0}+M_{1}$, the first order derivatives is less than 0 . So, with the increase of $t_{0}$, new energy enterprise generating capacity will decrease; when $2 \mathrm{M}_{2}<\mathrm{M}_{0}+\mathrm{M}_{1}$, the first order derivatives is more than 0 . So, with the increase of $t_{0}$, new energy enterprise generating capacity will increase.

Therefore, whether fossil energy or new energy enterprise, only reduce the unit carbon emissions as much as possible, is an important way to acquire more government subsidies and expand market occupancy. optimal equilibrium solution can be obtain: New energy power generation decrease; for fossil energy enterprises, when $2 t_{1}>t_{2}$, electrical generating capacity is decreased, when $2 t_{1}<t_{2}$, electrical generating capacity is increased. But because of social gross generation reduce, thus, the government should be appropriate to adjust the size of t0 after cancel the direct subsidies, so that meet the demand of social overall power generation.

\subsubsection{The optimal market price}

In this situation, according to the market inverse demand function can get the optimal price:

$$
\mathrm{P}_{1}=\frac{\mathrm{a}+\mathrm{C}_{1}+\mathrm{C}_{2}-\mathrm{t}_{1}-\mathrm{t}_{2}-2 \mathrm{t}_{0} \mathrm{M}_{0}^{\mathrm{A}}+\mathrm{t}_{0} \mathrm{M}_{1}+\mathrm{t}_{0} \mathrm{M}_{2}}{3}
$$

Thus we can see that if countries cancel direct subsidies for energy, will cause the electricity prices. Because $2 M_{0}^{\mathrm{A}}>\mathrm{M}_{1}+\mathrm{M}_{2}$, the first order derivatives of $t_{0}$ is less than 0 , so, the size of the $t_{0}$ is inversely proportional to the market price of electricity.

Combined with the above formulas available the maximum benefit of fossil energy and new energy enterprises respectively:

$$
\begin{aligned}
& \pi_{1}^{\mathrm{C} 1}=\mathrm{q}_{1}^{\mathrm{C} 1}\left[\mathrm{P}_{1}-\mathrm{C}_{1}+\mathrm{t}_{1}+\mathrm{t}_{0}\left(\mathrm{M}_{0}-\mathrm{M}_{1}\right)\right] \\
& \pi_{2}^{\mathrm{Cl}}=\mathrm{q}_{2}^{\mathrm{C} 1}\left[\mathrm{P}_{1}-\mathrm{C}_{2}+\mathrm{t}_{2}+\mathrm{t}_{0}\left(\mathrm{M}_{0}-\mathrm{M}_{2}\right)\right]
\end{aligned}
$$

3.2 Situation 2: $\mathrm{M}_{2}<\mathrm{M}_{0}<\mathrm{M}_{1}$

The second situation: government subsidies for enterprise of unit carbon emissions less than $\mathrm{M}_{0}^{\mathrm{B}}$ (to distinguish the different situation of $\mathrm{M}_{0}$, here with $\mathbf{M}_{0}^{\mathrm{B}}$ ), when enterprise of unit carbon emissions more than $\mathrm{M}_{0}^{\mathrm{B}}$, the government to the enterprise tax (the unit tax coefficient $r$ ). At this moment, $\mathrm{M}_{0}^{\mathrm{B}}<\mathrm{M}_{1}, \mathrm{M}_{2}<\mathrm{M}_{0}^{\mathrm{B}}$, revenue function is:

$$
\begin{aligned}
& \pi_{1}=\mathrm{q}_{1}\left[\mathrm{P}\left(\mathrm{q}_{1}+\mathrm{q}_{2}\right)-\mathrm{C}_{1}-\mathrm{r}\left(\mathrm{M}_{1}-\mathrm{M}_{0}^{\mathrm{B}}\right)\right] \\
& \pi_{2}=\mathrm{q}_{2}\left[\mathrm{P}\left(\mathrm{q}_{1}+\mathrm{q}_{2}\right)-\mathrm{C}_{2}+\mathrm{t}_{2}+\mathrm{t}_{0}\left(\mathrm{M}_{0}^{\mathrm{B}}-\mathrm{M}_{2}\right)\right]
\end{aligned}
$$

\subsubsection{The optimal equilibrium output}

Both producers choose their optimal equilibrium output, for the first order derivatives equal to zero, namely:

$$
\left\{\begin{array}{l}
\frac{\partial \pi_{1}}{\partial q_{1}}=a-2 b q_{1}-b q_{2}-C_{1}-r\left(M_{1}-M_{0}^{B}\right)=0 \\
\frac{\partial \pi_{2}}{\partial q_{2}}=a-b q_{1}-2 b q_{2}-C_{2}+t_{2}+t_{0}\left(M_{0}^{B}-M_{2}\right)=0
\end{array}\right.
$$

To:

$$
\left\{\begin{array}{l}
\mathrm{q}_{1}^{\mathrm{C} 2}=\frac{\mathrm{a}-2 \mathrm{C}_{1}+\mathrm{C}_{2}-2 \mathrm{r}\left(\mathrm{M}_{1}-\mathrm{M}_{0}^{\mathrm{B}}\right)-\mathrm{t}_{2}-\mathrm{t}_{0}\left(\mathrm{M}_{0}^{\mathrm{B}}-\mathrm{M}_{2}\right)}{3 \mathrm{~b}} \\
\mathrm{q}_{2}^{\mathrm{C} 2}=\frac{\mathrm{a}-2 \mathrm{C}_{2}+\mathrm{C}_{1}+2 \mathrm{t}_{2}+2 \mathrm{t}_{0}\left(\mathrm{M}_{0}^{\mathrm{B}}-\mathrm{M}_{2}\right)+\mathrm{r}\left(\mathrm{M}_{1}-\mathrm{M}_{0}^{\mathrm{B}}\right)}{3 \mathrm{~b}}
\end{array}\right.
$$

By the Nash equilibrium solution can be obtained that $\mathrm{t} 2, \mathrm{t} 0, \mathrm{M} 1, \mathrm{r}$, are inversely proportional to the fossil energy capacity of enterprise, and is directly proportional to the capacity of the new energy companies; $M_{2}$ is proportional to the fossil energy enterprise output, and the new energy companies is inversely proportional to the output; $M_{0}$ is inversely proportional to the fossil energy enterprise output, but when $2 t_{0}>r, M_{0}$ is proportional to the new energy enterprise output; when $2 \mathrm{t}_{0}<\mathrm{r}, \mathrm{M}_{0}$ is inversely proportional to the fossil energy enterprise output. Thus it is clear that fossil energy enterprise reduce unit carbon emission is a direct method for acquire state subsidies and expending market share.

(3) If countries cancel direct subsidies for energy $t_{1}$ and $t_{2}$, through the 
In this situation, according to the market inverse demand function can get the optimal price:

$\mathrm{P}_{2}=\frac{\mathrm{a}+\mathrm{C}_{1}+\mathrm{C}_{2}+\mathrm{r}\left(\mathrm{M}_{1}-\mathrm{M}_{0}^{\mathrm{B}}\right)-\mathrm{t}_{2}-\mathrm{t}_{0}\left(\mathrm{M}_{0}^{\mathrm{B}}-\mathrm{M}_{2}\right)}{3}$

Thus we can see that unit carbon tax coefficient $r$ is larger, the higher the market price; but unit of carbon emissions subsidies coefficient $t_{0}$ is larger, the lower the market price. Thus the government should be prudent adjust $\mathrm{t}_{0}$ and $\mathrm{r}$.

Combined with the above formulas available the maximum benefit of fossil energy and new energy enterprises respectively:

$$
\begin{aligned}
& \pi_{1}^{\mathrm{C} 2}=\mathrm{q}_{1}^{\mathrm{C} 2}\left[\mathrm{P}_{2}-\mathrm{C}_{1}-\mathrm{r}\left(\mathrm{M}_{1}-\mathrm{M}_{0}^{\mathrm{B}}\right)\right] ; \\
& \pi_{2}^{\mathrm{C} 2}=\mathrm{q}_{2}^{\mathrm{C} 2}\left[\mathrm{P}_{2}-\mathrm{C}_{2}+\mathrm{t}_{2}+\mathrm{t}_{0}\left(\mathrm{M}_{0}^{\mathrm{B}}-\mathrm{M}_{2}\right)\right] \\
& 3.3 \text { Situation } 3: \mathrm{M}_{0}<\mathrm{M}_{2}<\mathrm{M}_{1}
\end{aligned}
$$

The third situation: the government to the enterprise tax for enterprise of unit carbon emissions less than $\mathrm{M}_{0}^{\mathrm{C}}$ (to distinguish the different situation of $\mathrm{M}_{0}$, here with $\mathrm{M}_{0}^{\mathrm{C}}$ ). At this moment, $\mathrm{M}_{0}^{\mathrm{C}}<\mathrm{M}_{1}, \mathrm{M}_{2}>\mathrm{M}_{0}^{\mathrm{C}}$, revenue function is:

$$
\begin{aligned}
& \pi_{1}=\mathrm{q}_{1}\left[\mathrm{P}\left(\mathrm{q}_{1}+\mathrm{q}_{2}\right)-\mathrm{C}_{1}-\mathrm{r}\left(\mathrm{M}_{1}-\mathrm{M}_{0}^{\mathrm{C}}\right)\right] \\
& \pi_{2}=\mathrm{q}_{2}\left[\mathrm{P}\left(\mathrm{q}_{1}+\mathrm{q}_{2}\right)-\mathrm{C}_{2}-\mathrm{r}\left(\mathrm{M}_{2}-\mathrm{M}_{0}^{\mathrm{C}}\right)\right]
\end{aligned}
$$

\subsubsection{The optimal equilibrium output}

Both producers choose their optimal equilibrium output, for the first order derivatives equal to zero, namely:

$\left\{\begin{array}{l}\frac{\partial \pi_{1}}{\partial q_{1}}=a-2 b q_{1}-b q_{2}-C_{1}-r\left(M_{1}-M_{0}^{C}\right)=0 \\ \frac{\partial \pi_{2}}{\partial q_{2}}=a-b q_{1}-2 b q_{2}-C_{2}-r\left(M_{2}-M_{0}^{C}\right)=0\end{array}\right.$

To :

$\left\{\begin{array}{l}\mathrm{q}_{1}^{\mathrm{C} 3}=\frac{\mathrm{a}-2 \mathrm{C}_{1}+\mathrm{C}_{2}-\mathrm{r}\left(2 \mathrm{M}_{1}-\mathrm{M}_{2}-\mathrm{M}_{0}^{\mathrm{C}}\right)}{3 \mathrm{~b}} \\ \mathrm{q}_{2}^{\mathrm{C} 3}=\frac{\mathrm{a}-2 \mathrm{C}_{2}+\mathrm{C}_{1}-\mathrm{r}\left(2 \mathrm{M}_{2}-\mathrm{M}_{1}-\mathrm{M}_{0}^{\mathrm{C}}\right)}{3 \mathrm{~b}}\end{array}\right.$

The first derivative $\mathrm{r}$ is: $\frac{\partial \mathrm{q}_{1}^{\mathrm{C}}}{\partial \mathrm{r}}=\frac{\mathrm{M}_{2}+\mathrm{M}_{0}^{\mathrm{C}}-2 \mathrm{M}_{1}}{3 \mathrm{~b}}$ and $\frac{\partial \mathrm{q}_{2}^{\mathrm{C} 3}}{\partial \mathrm{r}}=\frac{\mathrm{M}_{1}+\mathrm{M}_{0}^{\mathrm{C}}-2 \mathrm{M}_{2}}{3 \mathrm{~b}}$.

When $\mathbf{M}_{1}>2 \mathbf{M}_{2}-\mathbf{M}_{0}^{\mathrm{C}}, \frac{\partial \mathrm{q}_{1}^{\mathrm{C} 3}}{\partial \mathrm{r}}<0$ and $\frac{\partial \mathrm{q}_{2}^{\mathrm{C} 3}}{\partial \mathrm{r}}>0$. With the increase of $\mathrm{r}$, fossil energy enterprise of generating capacity is reduced, new energy enterprises of generating capacity increase;

When $\frac{\mathrm{M}_{2}+\mathrm{M}_{1}}{2}<\mathrm{M}_{1}<2 \mathrm{M}_{2}-\mathrm{M}_{0}^{\mathrm{C}}, \frac{\partial \mathrm{q}_{1}^{\mathrm{C} 3}}{\partial \mathrm{r}}<0$ and $\frac{\partial \mathrm{q}_{2}^{\mathrm{C} 3}}{\partial \mathrm{r}}<0$. With the increase of $r$, both fossil energy and new energy enterprise of generating capacity are reduced;

When $\mathrm{M}_{1}<\frac{\mathrm{M}_{2}+\mathrm{M}_{1}}{2}, \frac{\partial \mathrm{q}_{1}^{\mathrm{C3}}}{\partial \mathrm{r}}>0$ and $\frac{\partial \mathrm{q}_{2}^{\mathrm{C} 3}}{\partial \mathrm{r}}<0$. With the increase of $\mathrm{r}$, new energy enterprise of generating capacity is reduced, fossil energy enterprises of generating capacity increase. Thus, countries should be confirms rationally the value of $r$ according to the relationship of $M_{1}$ and $\mathrm{M}_{2}$.

\subsubsection{The optimal market price}

In this situation, according to the market inverse demand function can get the optimal price:

$P_{3}=\frac{a+C_{1}+C_{2}+r\left(M_{1}+M_{2}-2 M_{0}^{c}\right)}{3}$

Thus we can see that $r$ is proportional to the market price.

Combined with the above formulas available the maximum benefit of fossil energy and new energy enterprises respectively:

$$
\begin{aligned}
& \pi_{1}^{\mathrm{C} 3}=\mathrm{q}_{1}^{\mathrm{C} 3}\left[\mathrm{P}_{3}-\mathrm{C}_{1}-\mathrm{r}\left(\mathrm{M}_{1}-\mathrm{M}_{0}^{\mathrm{C}}\right)\right] ; \\
& \pi_{2}^{\mathrm{C} 3}=\mathrm{q}_{2}^{\mathrm{C} 3}\left[\mathrm{P}_{3}-\mathrm{C}_{2}-\mathrm{r}\left(\mathrm{M}_{2}-\mathrm{M}_{0}^{\mathrm{C}}\right)\right]
\end{aligned}
$$

3.4 Synthetic discussion government revenue under three kinds of situation

According to the set of $\mathrm{M}_{0}$ range, can summarize three kinds of situations, as shown in table 1 :

Table 1

\begin{tabular}{c|ccc}
\hline The range of the $\mathrm{M}_{0}$ & $\begin{array}{l}\text { The optimal } \\
\text { equilibrium output }\end{array}$ & $\begin{array}{l}\text { The optimal } \\
\text { market price }\end{array}$ & Government revenues \\
\hline $\mathrm{M}_{0}^{\mathrm{A}}>\mathrm{M}_{1}>\mathrm{M}_{2}$ & $\left\{\begin{array}{l}\mathrm{q}_{1}^{\mathrm{Cl}} \\
\mathrm{q}_{2}^{\mathrm{C} 1}\end{array}\right.$ & $\mathrm{P}_{1}$ & $\pi_{\mathrm{G}}^{\mathrm{Cl}}=\mathrm{q}_{1}^{\mathrm{Cl}}\left(\mathrm{P}_{1}-\mathrm{C}_{1}\right)+\mathrm{q}_{2}^{\mathrm{Cl}}\left(\mathrm{P}_{1}-\mathrm{C}_{2}\right)$ \\
\hline $\mathrm{M}_{1}>\mathrm{M}_{0}^{\mathrm{B}}>\mathrm{M}_{2}$ & $\left\{\begin{array}{l}\mathrm{q}_{1}^{\mathrm{C} 2} \\
\mathrm{q}_{2}^{\mathrm{C} 2}\end{array}\right.$ & $\mathrm{P}_{2}$ & $\pi_{\mathrm{G}}^{\mathrm{C} 2}=\mathrm{q}_{1}^{\mathrm{C2}}\left(\mathrm{P}_{2}-\mathrm{C}_{1}\right)+\mathrm{q}_{2}^{\mathrm{C2}}\left(\mathrm{P}_{2}-\mathrm{C}_{2}\right)$ \\
\hline $\mathrm{M}_{1}>\mathrm{M}_{2}>\mathrm{M}_{0}^{\mathrm{C}}$ & $\left\{\begin{array}{l}\mathrm{q}_{1}^{\mathrm{C} 3} \\
\mathrm{q}_{2}^{\mathrm{C} 3}\end{array}\right.$ & $\mathrm{P}_{3}$ & $\pi_{\mathrm{G}}^{\mathrm{C} 3}=\mathrm{q}_{1}^{\mathrm{C} 3}\left(\mathrm{P}_{3}-\mathrm{C}_{1}\right)+\mathrm{q}_{2}^{\mathrm{C} 3}\left(\mathrm{P}_{3}-\mathrm{C}_{2}\right)$ \\
\hline
\end{tabular}

Introductions: for the convenience of calculation, assuming that $t_{0}=r$. Through calculation and comparison, we can obtain that the relationships of size among the price are $\mathrm{P}_{1}<\mathrm{P}_{2}<\mathrm{P}_{3}$, that the relationships of size among the government revenues are $\pi_{\mathrm{G}}^{\mathrm{C} 1}>\pi_{\mathrm{G}}^{\mathrm{C} 2}>\pi_{\mathrm{G}}^{\mathrm{C} 3}$. Although the lower the value of the $\mathrm{M}_{0}$, the government revenues also declined, but it will prevent damage to the environment. In other words, it will bring environmental benefits for the country, can better protect the environment, thus to the road of sustainable development.

\section{Conclusion and Prospect}

Through the above calculation and analysis, I put forward several policy proposals:

(1) Cancel the direct subsidies for energy, and only subsidies for enterprise according to the unit carbon emissions can effectively reduce the environment pollution.

(2) The relationship between the $M_{0}$ and $M_{1}$ and $M_{2}$, directly affect the market price, thus, countries should reasonable adjustment of electricity prices according to the relationships among $M_{0}$ and $M_{1}$ and $\mathrm{M}_{2}$.

(3) $t_{0}$ and $r$ size will directly affect the capacity of energy enterprises and production. Thus, countries should be confirms rationally the value of $r$ and $t_{0}$ according to the relationship of $M_{1}$ and $M_{2}$, so that can better development of new energy.

(4) When $M_{0}$ is $M_{0}^{B}$, the comprehensive income is the largest of government. In other words, not only meets economic development, but also can protect environment. Thus, the government should adjust $\mathrm{M}_{0}$ towards the $\mathbf{M}_{0}^{\mathrm{B}}$

This paper is based on the model analysis, is a theoretical model, and lack of empirical analysis. Thus further on fossil energy and new energy enterprises for empirical analysis, not only good reaction fact, but also can enact correlatively more reliably and more reasonable policy.

\section{References}

[1] Lin Boqiang, Dou Yijie. Chinese energy subsidies reformation and effective energy subsidies[J]. Social Sciences in China, 2016, (10):52$71+202-203$

[2] Zhu Qinghua, Dou YIjie. Based on analysis of government subsidy game 
model of green supply chain management[J]. Journal of Management Sciences in China, 2011, 06:86-95;

[3] Liu Yihong. In the process of new energy industry development game equilibrium between government and enterprises[J]. Seeker, 2013,09:5355 ;

[4] Zhang Guoxing, Zhang Xutao, Wang Yingluo, Guo Dongmei. Energy conservation and emissions reduction and government subsidies of optimal boundary problem research [J]. Journal of Management Sciences in China, 2014, 11:129-138;

[5] Zhang Xutao. Game problem research between government and enterprises based on energy conservation and emissions reduction subsidy policy of enterprise game studies []].Lan Zhou University, 2014
[6] He Lihong, Wang Xiu. The government and core enterprise in low carbon supply chain evolutionary game model[J]. China Population Resources and Environment, 2014,11, s1: 27-30;

[7] Hammond D,Beullens P.Closedloop supply chain network equilibrium under legislation[J].European Journal of Operational Research ,2007,183 (2): 895-908;

[8] Rui Zhao , Gareth Neighbour, Jiaojie Han, et al · Using game theory to describe strategy selection for environmental risk and carbon emissions reduction in the green supply chain[J] - Journal of Loss Prevention in the Process Industries , 2012(25): 927 - 936. case[J].Annals of Tourism Research,2006(4):1018-1035. 